\title{
2. CORRELATIONS OF SEDIMENT LITHOSTRATIGRAPHY, DOWNHOLE LOGS, AND SEISMIC REFLECTORS AT SITE 418 1
}

\author{
R. L. Carlson, Texas A\&M University, College Station, Texas ${ }^{2}$ \\ R. H. Wilkens, Massachusetts Institute of Technology, Cambridge, Massachusetts ${ }^{3}$ \\ and \\ Dan Moos and Cristina Broglia, Lamont-Doherty Geological Observatory, Palisades, New York ${ }^{4}$
}

\begin{abstract}
We have correlated the spectral gamma-ray log from the 324-m sediment section at Hole 418A with core data from Holes 418A and 418B to develop a more detailed lithostratigraphic model for Site 418 and a more precise correlation of lithologic boundaries with seismic reflections. In general, log-unit boundaries can be resolved to within about $1 \mathrm{~m}$ (below seafloor). Except for lithologic Unit III, all units defined by coring are well defined by the logs and depths to unit boundaries defined by logging are consistent with constraints imposed by the cores. The logs also indicate the existence of several subunits not defined by coring. Each of five reflectors correlates with a unit boundary. In particular, reflectors at 0.21 and $0.29 \mathrm{~s}$ (two-way traveltime, below seafloor), which have been identified as horizon $\mathrm{A}^{\mathrm{c}}$ and horizon $\beta$ by Senske and Stephen (this volume), correlate with the base of the Eocene clays of Unit IV and with the top of the "black clay" sequence, Unit VI.
\end{abstract}

\section{INTRODUCTION}

Many reasons can be given for logging sediment sections at DSDP/ODP sites. Among the most important are that the logs can serve as a guide for defining lithologic units, or, where core recovery is poor, for locating unit boundaries more precisely. Downhole logs also provide constraints for correlating the lithostratigraphy of the site with seismic-reflection records to extend drilling results away from the hole.

Site 418 was drilled at the southern end of the Bermuda Rise in 1977 (Donnelly, Francheteau, et al., 1980). At Hole 418A, a basement hole, the 324-m sediment section was spot cored; of the $137.5 \mathrm{~m}$ cored, $58 \mathrm{~m}$ was recovered. Only $18 \%$ of the section was actually sampled. Hole 418B, $130 \mathrm{~m}$ north of Hole 418A, was cored continuously to basement; $173 \mathrm{~m} \mathrm{(52 \% )}$ was recovered, however, recovery was not evenly distributed. Over the interval from 110 to $320 \mathrm{~m}$, the recovery rate was just $35 \%$. Furthermore, these holes were cored prior to the development of the hydraulic piston core (HPC) barrel, and the cored sediments are badly disturbed. Thus, the lithologic column defined on the basis of the cored sediments is, at best, tentative.

ODP Leg 102 returned to Hole 418A in early 1985 with the primary objective of logging the oceanic basement formation (Salisbury, Scott, et al., 1986). The 324-m sediment section was logged through the pipe using neutron porosity and spectral gamma-ray (NGT) tools. From a quantitative point of view the quality of the porosity and NGT logs is poor because of neutron and gamma-ray absorption by the borehole fluid and the pipe; nevertheless, the logs can be used in a qualitative way to define unit boundaries.

Our objectives in this note are (1) to clarify the lithostratigraphy of the sediment column at Site 418 through a close comparison of the coring record with the detailed record provided by

\footnotetext{
${ }^{1}$ Salisbury, M. H., Scott, J. H., et al., 1988. Proc. ODP, Sci. Results., 102: College Station, TX (Ocean Drilling Program).

2 Address: Geodynamics Research Institute, Texas A\&M University, College Station, TX 77840.

${ }^{3}$ Address: Earth Resources Laboratory, Massachusetts Institute of Technology, Cambridge, MA 02139.

4 Addresses: Lamont-Doherty Geological Observatory, Palisades, NY 10964; (Moos, present address) Department of Geophysics, Stanford University, Stanford, CA 94305.
}

the NGT gamma log obtained on ODP Leg 102 and (2) to establish a refined correlation of the lithostratigraphy with seismic reflections at the site.

\section{LOGGING AND CORING CORRELATIONS}

The NGT logging tool is sensitive to potassium $(\mathrm{K})$, thorium $(\mathrm{Th})$, and uranium (U) contents; because these elements occur in clay minerals, the log reflects the mineralogical composition of the sediments. We therefore expect a fairly high degree of correlation between the log and the lithology of the logged interval. However, some discrepancies between lithologic boundaries determined by coring and those from the logs are to be expected for several reasons. First, coring and logging employed two different ships. Coring depths are based on the length of pipe below the rig floor of Glomar Challenger whereas log depths are based on the length of logging cable deployed from JOIDES Resolution. A possible discrepancy is indicated by the fact that the seafloor was felt at $5519 \mathrm{~m}$ with the drill string but that the top of the sediment section was detected at $5510 \mathrm{~m}$ in logging the hole. However, both drilling and logging operations indicate the top of the basaltic basement at $324 \mathrm{~m}$ below seafloor (mbsf), suggesting that discrepancies in coring and logging depths are small. Second, the Hole 418A sediment section was spot cored, so logging results from Hole $418 \mathrm{~A}$ best compare with the morecomplete coring record at Hole $418 \mathrm{~B}, 130 \mathrm{~m}$ to the north. The seismic-reflection profiles across Site 418 (Donnelly, Francheteau, et al., 1980; p. 393) suggest uniform stratigraphy over distances of several hundred meters, but slight differences are nevertheless to be expected. Finally, errors in depths to lithologic unit boundaries arise from poor recovery and spot coring. Such uncertainties can be quite large and are larger if the boundary is not recovered in coring. We have attempted to account for these uncertainties in the following analysis.

Figure 1 shows the Leg 102 NGT and neutron porosity logs from the sediment section of Hole $418 \mathrm{~A}$, the coring record and lithologic units as interpreted by DSDP Legs 51-53 scientific parties (Donnelly, Francheteau, et al., 1980), and corresponding units inferred from the logs. Log and lithologic unit intervals are summarized in Table 1.

Unit I, a brown pelagic clay with nannofossil zones, extends to a depth of at least 6 mbsf in Hole 418 , but was not cored at Hole 418A. In Hole 418B the contact between Unit I and Sub- 
Table 1. Summary of lithologic and $\log$ units.

\begin{tabular}{|c|c|c|c|c|c|c|}
\hline \multirow[b]{2}{*}{ Lithology } & \multicolumn{2}{|c|}{ Hole $418 \mathrm{~A}$} & \multicolumn{2}{|c|}{ Hole 418B } & \multicolumn{2}{|c|}{ Hole 418A Log } \\
\hline & Unit & $\begin{array}{l}\text { Depth } \\
\text { (mbsf) }\end{array}$ & Unit & $\begin{array}{l}\text { Depth } \\
\text { (mbsf) }\end{array}$ & Unit & $\begin{array}{l}\text { Depth } \\
\text { (mbsf) }\end{array}$ \\
\hline $\begin{array}{l}\text { Brown pelagic clay with } \\
\text { nannofossil hori- } \\
\text { zons }\end{array}$ & I & - & I & $0-16$ & 1 & $0-19$ \\
\hline $\begin{array}{l}\text { Yellow brown pelagic } \\
\text { clay }\end{array}$ & Ha & - & IIa & $16-73$ & $2 \mathrm{a}$ & $19-77$ \\
\hline Pale orange pelagic clay & IIb & -151 & IIb & $73-139$ & $2 b$ & $77-143$ \\
\hline $\begin{array}{l}\text { Dark gray brown } \\
\text { pelagic clay with } \\
\text { zeolites }\end{array}$ & III & $151-159$ & III & $139-158$ & 3 & $143-160$ \\
\hline $\begin{array}{l}\text { Dark gray brown to red } \\
\text { brown pelagic clay } \\
\text { with radiolarians }\end{array}$ & IV & $159-178$ & IV & $158-177$ & 4 & $160-178$ \\
\hline $\begin{array}{l}\text { Dark gray brown to red } \\
\text { brown pelagic clay }\end{array}$ & Va & $178-206$ & $\mathrm{Va}$ & $177-196$ & $5 \mathrm{a}$ & $178-198$ \\
\hline $\begin{array}{l}\text { Multicolored zeolitic } \\
\text { clay }\end{array}$ & $\mathrm{Vb}$ & - & Va & $196-236$ & $5 b$ & $198-244$ \\
\hline $\begin{array}{l}\text { Multicolored claystones, } \\
\text { chalks, and radio- } \\
\text { larian sands }\end{array}$ & VI & $235-292$ & VI & $236-292$ & $\begin{array}{l}6 \mathrm{a} \\
6 \mathrm{~b}\end{array}$ & $\begin{array}{l}244-263 \\
263-294\end{array}$ \\
\hline $\begin{array}{l}\text { Red brown chalks to } \\
\text { radiolarian marls }\end{array}$ & VIIa & $292-303$ & VIIa & $292-302$ & $7 \mathrm{a}$ & $294-302$ \\
\hline $\begin{array}{l}\text { Black and green clay- } \\
\text { stones, marls, and } \\
\text { chert }\end{array}$ & VIIb & $303-320$ & VIIb & $302-320$ & $7 \mathrm{~b}$ & $302-324$ \\
\hline Nannofossil chalk & VIII & $320-324$ & - & - & - & - \\
\hline Basalt & - & $324-$ & - & - & - & - \\
\hline
\end{tabular}

unit IIa, which does not contain nannofossils, lies between Cores 2 and 3, at a depth of 11 to 17 mbsf. Because of the presence of nannofossil horizons, Unit I is characterized by lower levels of natural gamma radiation than Unit II; we find an abrupt increase in Th content at 19 mbsf. Log Unit 1 extends from 0 to $19 \mathrm{msbf}$ and correlates with lithologic Unit I.

Subunits IIa and IIb are recognized within lithologic Unit II. Subunit IIa is described as a dark to moderate yellow brown hemipelagic mud. Subunit IIb is a pale yellow gray, homogeneous, fine-grained pelagic clay. The Subunit IIa/Subunit IIb lithologic boundary was not cored in Hole 418A, and lies between 72 and 76 mbsf in Hole 418B. The Hole 418A logs show a clear change at $77 \mathrm{~m}$. At this depth the apparent porosity decreases abruptly from $70 \%$ to about $60 \%$, and there is a minimum in total gamma radiation, which reflects a minimum in $\mathrm{Th}$ content. Below the break (between 77 and 91 mbsf), Th contents are higher than they are above it. Within log Unit $2 a$, which we assign to the interval 19 to $77 \mathrm{mbsf}$, the character of the NGT $\log$ indicates relatively uniform composition. Log Unit 2a correlates well with lithologic Subunit IIa.

The base of Unit II is difficult to reconcile with the logs. The underlying unit (III) is described as a dark gray brown pelagic clay, but pale orange gray interbeds and mottles characteristic of Subunit IIb continue. Unit III may thus be transitional. In Hole $418 \mathrm{~A}$ the boundary is located within Core 5, Section 2 (151-153 mbsf). In Hole 418B the lithologic boundary between Subunit IIb and Unit III lies in the depth interval 136-148 mbsf. Unfortunately these intervals do not overlap. The logs indicate an abrupt decrease in $\mathrm{K}$ and $\mathrm{Th}$ and an increase in $\mathrm{U}$ at $143 \mathrm{mbsf}$. We take this break, which correlates with the Subunit IIb/Unit III boundary in Hole $418 \mathrm{~B}$, to be the base of $\log$ Unit $2 \mathrm{~b}$. We note, however that there is also a subtle change in the character of the log at about $150 \mathrm{mbsf}$, which might represent the lithologic change in Hole $418 \mathrm{~A}$.

Part of the ambiguity in identifying the lithologic Subunit $\mathrm{IIb} /$ Unit III boundary in the log derives from the fact that the logs reveal three additional subunits within Unit $2 b$ (Subunit IIB). The top of Unit $2 b$ (designated Subunit $2 b_{1}$ ) is character- ized by high Th and $\mathrm{K}$ concentrations extending from 77 to 91 mbsf. From 91 to 124 mbsf (Subunit $2 b_{2}$ ) the logs are similar in character to Unit $2 \mathrm{a}$. At $124 \mathrm{~m}$, Th and $\mathrm{K}$ again increase and $\mathrm{U}$ decreases sharply; Subunit $2 b_{3}$ is thus characterized by high Th and very low $U$ concentrations, and extends to a depth of 143 mbsf. There is nothing in the lithologic descriptions of Unit IIb that distinguishes Subunits $2 b_{1}, 2 b_{2}$, and $2 b_{3}$. X-ray analyses (Mann and Müller, 1980) of sediments from Hole 418B indicate that the smectite content of Subunit IIa (Unit 2a) is fairly uniform and slightly lower than the smectite content of Subunit IIb (Unit 2b). Furthermore, the indicated smectite contents are highest in the intervals corresponding to Subunits $2 b_{1}$ and $2 b_{3}$, suggesting that Subunits $2 b_{1}, 2 b_{2}$, and $2 b_{3}$ may differ in clay mineralogy. However, high smectite contents continue through Unit III, where Th and $\mathrm{K}$ contents are lower, and the suggested correlation of the logs with smectite content must therefore be regarded as very tentative. Thus, the base of $\log$ Subunit $2 b_{3}$ (i.e., the bottom of Unit $2 \mathrm{~b}$ ) cannot be clearly associated with a lithologic boundary; the interval between 143 and $150 \mathrm{~m}$ is similar to Subunit $2 b_{2}$ and might belong to lithologic Subunit IIb, as suggested by the core descriptions from Hole 418A. Except for this uncertainty, $\log$ Unit $2 \mathrm{~b}$ correlates well with Subunit IIb.

The base of lithologic Unit III, a dark gray brown pelagic clay containing zeolites, is difficult to define in the logs. Coring in Hole 418A indicates a depth of 159 to 164 mbsf. Because of poor recovery, the depth is also poorly constrained in Hole 418B (153 to $166 \mathrm{mbsf}$ ). There is a slight increase in Th and a small step decrease in $\mathrm{U}$ at $160 \mathrm{mbsf}$, which we tentatively identify as the base of $\log$ Unit 3 , indicated by the heavy dashed line in Figure 1. Unit 3 correlates then, although not definitively, with Unit III.

Lithologic Unit IV is a dark gray brown to red brown pelagic clay containing radiolarians. As noted above, the top of log Unit 4 is poorly defined. The base of the corresponding lithologic Unit IV is poorly constrained in Hole 418A; owing to the washed interval below Core $418 \mathrm{~A}-7$ and poor recovery in Core 418A-8, the Unit IV/Subunit Va boundary might be at a depth anywhere between 173 and about 206 mbsf. In Hole 418B, this boundary lies in the interval between 171 and $177 \mathrm{mbsf}$. In the logs, the Unit 4/Unit 5a contact is clearly defined at $178 \mathrm{mbsf}$ by very low $\mathrm{Th}$ and $\mathrm{K}$ concentrations and an abrupt drop in $\mathrm{U}$ content. Below this depth Th and $\mathrm{K}$ contents rise to the higher values characteristic of Unit 5a. A meter or so of nannofossil chalk recovered in Core 418B-19 (168-177 mbsf) may have come from the boundary and would account for the low values of Th and $\mathrm{K}$ at the contact. The Unit 4/Unit 5a contact correlates well with the contact between lithologic Unit IV and Subunit Va.

Log Unit $5 \mathrm{a}$ is characterized by high Th and $\mathrm{K}$ and very low $\mathrm{U}$ contents. Thorium concentration increases markedly with depth and the Unit $5 \mathrm{a} /$ Unit $5 \mathrm{~b}$ contact is indicated by a sharp drop in Th at 198 mbsf. In Hole 418B the contact between Units $\mathrm{Va}$ and $\mathrm{Vb}$ is within Core 8 , but because of very low recovery the boundary might be at a depth anywhere between 197 and 206 mbsf. In Hole 418B the Unit Va/Unit $\mathrm{Vb}$ boundary is between 195 and 200 mbsf. The Unit $\mathrm{Va} /$ Unit $\mathrm{Vb}$ contact is also associated with a marked increase of shear strength and compressional-wave velocities that occurs between 190 and $200 \mathrm{mbsf}$ (Donnelly, Francheteau, et al., 1980). Unit 5a and Subunit Va correlate very well.

Lithologic Subunit $\mathrm{Vb}$ is a multicolored (pale orange, brown to pale green) zeolitic clay. The depth to the Subunit $\mathrm{Vb} /$ Unit VI contact in Hole $418 \mathrm{~A}$ is utterly unconstrained. Because of very poor recovery in Cores $418 \mathrm{~A}-8$ and $418 \mathrm{~A}-9$, and the large washed interval between them, the boundary might be at any depth between 197 and 245 mbsf. The contact defined in Sample $418 \mathrm{~B}-26-1,90 \mathrm{~cm}$, has a depth range of 235 to $244 \mathrm{mbsf}$. Log Unit $5 b$ has a lower Th content and a higher $U$ content than 
Unit 5a. An interval characterized by very low $\mathrm{Th}$ and $\mathrm{K}$ contents is observed between 231 and 234 mbsf. However, the interval between 234 and 244 mbsf is very much the same as that above 231 mbsf. We therefore chose $244 \mathrm{mbsf}$ as the bottom of $\log$ Unit $5 \mathrm{~b}$ and suggest that lithologic Subunit $\mathrm{Vb}$ also extends to that depth. The interval between 231 and $234 \mathrm{mbsf}$ is probably a calcareous layer that lies within a washed interval in Hole $418 \mathrm{~A}$ and either is not present or was not recovered in Hole 418B.

Lithologic Unit VI consists of multicolored claystones, nannofossil chalks, marls, and radiolarian sands. In the logs, the top of Unit 6 (at 244 mbsf) is marked by a sharp drop in total gamma radiation and a slight increase in apparent porosity. Low concentrations of $\mathrm{Th}$ and $\mathrm{K}$ continue to a depth of $263 \mathrm{mbsf}$, where $\mathrm{Th}$ and $\mathrm{K}$ increase and apparent porosity decreases slightly. This interval was washed in Hole $418 \mathrm{~A}$, but core descriptions and X-ray diffraction analyses (Mann and Müller, 1980) from Hole $418 \mathrm{~B}$ indicate that carbonates are present in Unit VI above 265 mbsf but absent below that depth. Thus, log Unit 6 consists of two subunits; Unit 6 a (245-263 mbsf) displays low levels of radioactivity and correlates with the interval containing carbonates, whereas the underlying Unit $6 \mathrm{~b}$ is characterized by higher $\mathrm{Th}, \mathrm{K}$, and $\mathrm{U}$ contents and a slightly lower apparent porosity. Unit $6 \mathrm{~b}$ extends to a depth of $294 \mathrm{mbsf}$, where Th, K, and U contents decrease markedly.

In Hole 418A the base of Unit VI is again poorly constrained because of poor recovery, and might be anywhere in the interval 283 to 300 mbsf. In Hole 418 B the bottom of Unit VI is at a depth of 285 to 300 mbsf. A depth of 294 mbsf to the base of Unit $6 \mathrm{~b}$ is thus consistent with constraints imposed by coring.

Lithologic Unit VII is complex. Subunit VIIa, which consists of interbedded marls and chalks passing downward into dark reddish brown mudstones, represents an oxidized interval within the "black clay facies"; Subunit VIIb is similar to Unit VI and consists of green and black claystones, marls, and cherts. The Subunit VIIa/Subunit VIIb contact is between 303 and 310 mbsf in Hole 418A and between 302 and about 309 mbsf in Hole 418B. Although Subunit VIIa is defined by color (there is no marked change in composition at the unit boundary according to the core descriptions, and the NGT log may therefore correlate poorly with the lithologic units), we nevertheless recognize Subunit $7 \mathrm{a}_{1}$, an interval of low Th and K contents between 294 and 297 mbsf, which correlates with the calcareous sediments at the top of Subunit VIIa. The underlying log subunit, $7 a_{2}$, exhibits Th and $\mathrm{K}$ contents similar to those of Unit $6 \mathrm{~b}$, and extends to a depth of 302 mbsf. Unit 7a represents the dark reddish brown mudstones of the lower part of Subunit VIIa. Log Unit 7a thus correlates with lithologic Subunit VIIa. Log Unit $7 \mathrm{~b}$ is characterized by low $\mathrm{Th}$ and $\mathrm{K}$ contents and high $\mathrm{U}$ content and is similar in character to Unit $6 \mathrm{a}$. Unit $7 \mathrm{~b}$ occupies the interval from 302 mbsf to the top of oceanic basement at 324 mbsf and correlates with Subunit VIIb and Unit VIII, which consist of claystones, marls, and chalks.

Depths to lithologic and log unit boundaries described in the foregoing paragraphs are summarized in Table 2. On the whole, lithologic-unit boundaries correspond very well with recognizably distinct units defined by the NGT log. Log Units 1 and 2a correspond to lithologic Unit I and Subunit IIa. Unit $2 b$ is well defined and, except for some ambiguity in the depth to the base of Subunit IIb, correlates well with the lithologic unit. Three subunits within Subunit IIb (Unit 2b) that are not recognized in the lithologic descriptions are clearly defined by the NGT log. Unit III is the only lithologic unit that is difficult to identify in the log. The top of Unit 3 is sharply defined at 143 mbsf. A boundary at this depth is consistent with the coring results in Hole 418B, but lies about $7 \mathrm{~m}$ above the contact recognized in Hole 418A; a less obvious change in the logs, which occurs at
150 mbsf, may correspond with the lithologic boundary. The base of Unit 3 is poorly defined, but can be chosen to lie at 160 mbsf, a depth consistent with the drilling results. The bottom of log Unit 4 (lithologic Unit IV) is well defined. Log Unit 5a and lithologic Subunit Va also correlate closely, as do Units 6 and VI. In the case of Unit VI, the character of the logs reflects the composition so well that two subunits can be identified, a calcareous upper interval (Unit 6a) and a noncalcareous underlying unit (6b). Two subunits within Subunit VIIa are also defined by the log. Subunit $7 a_{1}$ corresponds to a thin layer of nannofossil chalk, whereas Subunit $7 \mathrm{a}_{2}$ reflects an underlying clayrich interval. Unit $7 \mathrm{~b}$ correlates well with the chalks and marls of Subunit VIIb and Unit VIII, which overlie igneous basement.

\section{CORRELATION WITH THE SEISMIC-REFLECTION RECORD}

Seismic-reflection records represent the only means of applying, or extending, drilling results away from the hole. Correlating lithologic boundaries with seismic reflectors is thus an important objective.

In the single-channel Glomar Challenger profile across Site 418, Donnelly, Francheteau, et al. (1980) recognized two events. One is the basement reflector at $0.40 \mathrm{~s}$ two-way traveltime (TWT) below seafloor. They proposed a correlation of the other reflector, at $0.20 \mathrm{~s}$, with the top of the Eocene zeolitic clay of Unit III at 150 mbsf, although they recognized a possible alternative correlation with the top of Unit V at a depth of $178 \mathrm{mbsf}$.

Senske and Stephen (this volume) have analyzed data from an extensive reflection survey conducted in the vicinity of Site 418 by R/V Fred H. Moore during Leg 102 . They identified four reflectors designated red, green, yellow, and blue, and although none of the survey lines passes directly over Hole 418A, these reflections can be correlated with the drilling record. Near Hole $418 \mathrm{~A}$ these reflections occur at $0.11,0.20,0.30$, and $0.36 \mathrm{~s}$, respectively. Using an average velocity of $1.6 \mathrm{~km} / \mathrm{s}$, Senske and Stephen estimated the depths to be about 90 (red), 160 (green), 240 (yellow), and 290 mbsf (blue). The red reflector lies within Unit II, and Senske and Stephen (this volume) tentatively propose a correlation with possible volcanic ash layers. The green reflector can be associated with the zeolitic clays of Unit III. Senske and Stephen suggest that this event is horizon $A^{c}$, the strongest reflector in the horizon A complex, which is widespread in this region and associated with diagenetic Eocene chert elsewhere (Ewing and Ewing, 1963; Tucholke, 1979; Tucholke and Mountain, 1979). The yellow reflector, near $240 \mathrm{mbsf}$, is close to the contact between Units V and VI, where zeolitic clays of Late Cretaceous(?) age are underlain by Albian-Cenomanian chalk, claystone, marl, and radiolarian sand. Noting that horizon $\beta$ is associated with an Early Cretaceous transition from carbonate to noncalcareous deposition in the western North Atlantic (Tucholke and Mountain, 1979), Senske and Stephen have identified the yellow reflector as horizon $\beta$ (i.e., the top of the "black clay facies", Unit VI). Finally, they correlate the blue reflector with the top of igneous basement, although the estimated depth is $290 \mathrm{mbsf}$, as opposed to the $324 \mathrm{mbsf}$ depth to basement found by drilling.

Carlson et al. (1986) have made a statistical analysis of reflection times and depths to 233 reflecting horizons at 154 DSDP sites. The results indicate that depths can be predicted to within 13 mbsf (rms error) for traveltimes less than about $0.4 \mathrm{~s}$ and to within 37 mbsf for traveltimes between 0.4 and about $1.3 \mathrm{~s}$ by an empirical equation

$$
\mathrm{z}(\mathrm{km})=-3.03 \ln (1-0.263 \mathrm{~T}),
$$

where T is TWT (bsf) in seconds. The Hole 418A basement reflector at $0.40 \mathrm{~s}$ (Donnelly, Francheteau, et al., 1980) was used 


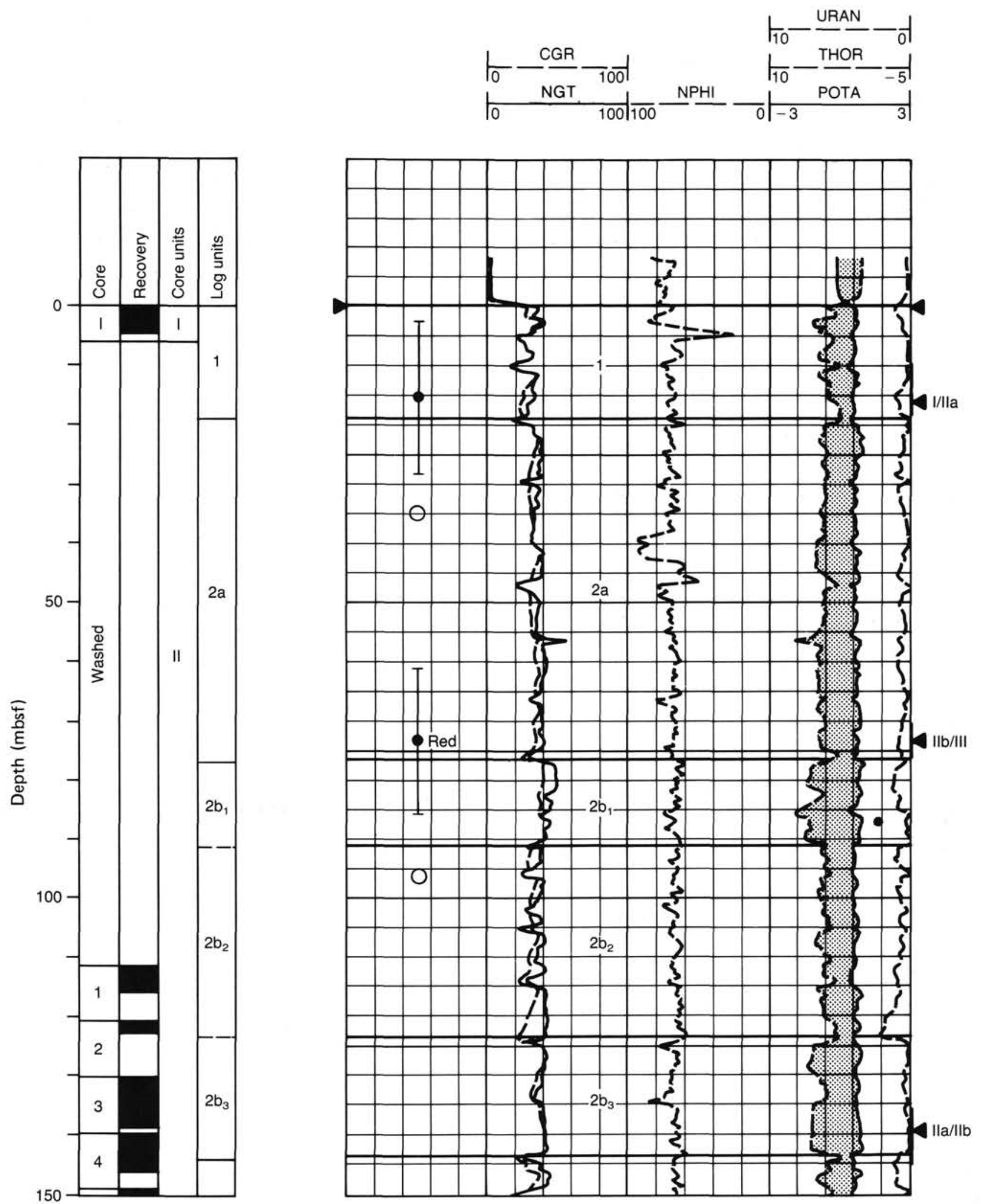

Figure 1. Coring and logging stratigraphy, Site 418. Logs shown are total standard gamma-ray $(\mathrm{NGT}=\mathrm{U}+\mathrm{Th}+\mathrm{K})$ and calculated gamma-ray (CGR $=K+T h$ ) (GAPI units), uranium and thorium (ppm), potassium (weight $\%$ ), and apparent (raw) neutron porosity (NPHI, \%). On the left are the Hole 418A coring and recovery records, lithologic units denoted by Roman numerals, and log units denoted by Arabic numerals. Solid triangles on left and right margins of the downhole log indicate depths to lithologic boundaries in Holes $418 \mathrm{~A}$ and $418 \mathrm{~B}$, respectively; associated heavy vertical bars show possible ranges of depth. Heavy horizontal lines across logs indicate log-unit boundaries. Light lines indicate log subunits. Circles in left column of log show calculated depths corresponding to reflection events; solid circles show primary events and open circles, second pulses. Error bars show uncertainty of $\pm 13 \mathrm{~m}$ in calculated depths. 


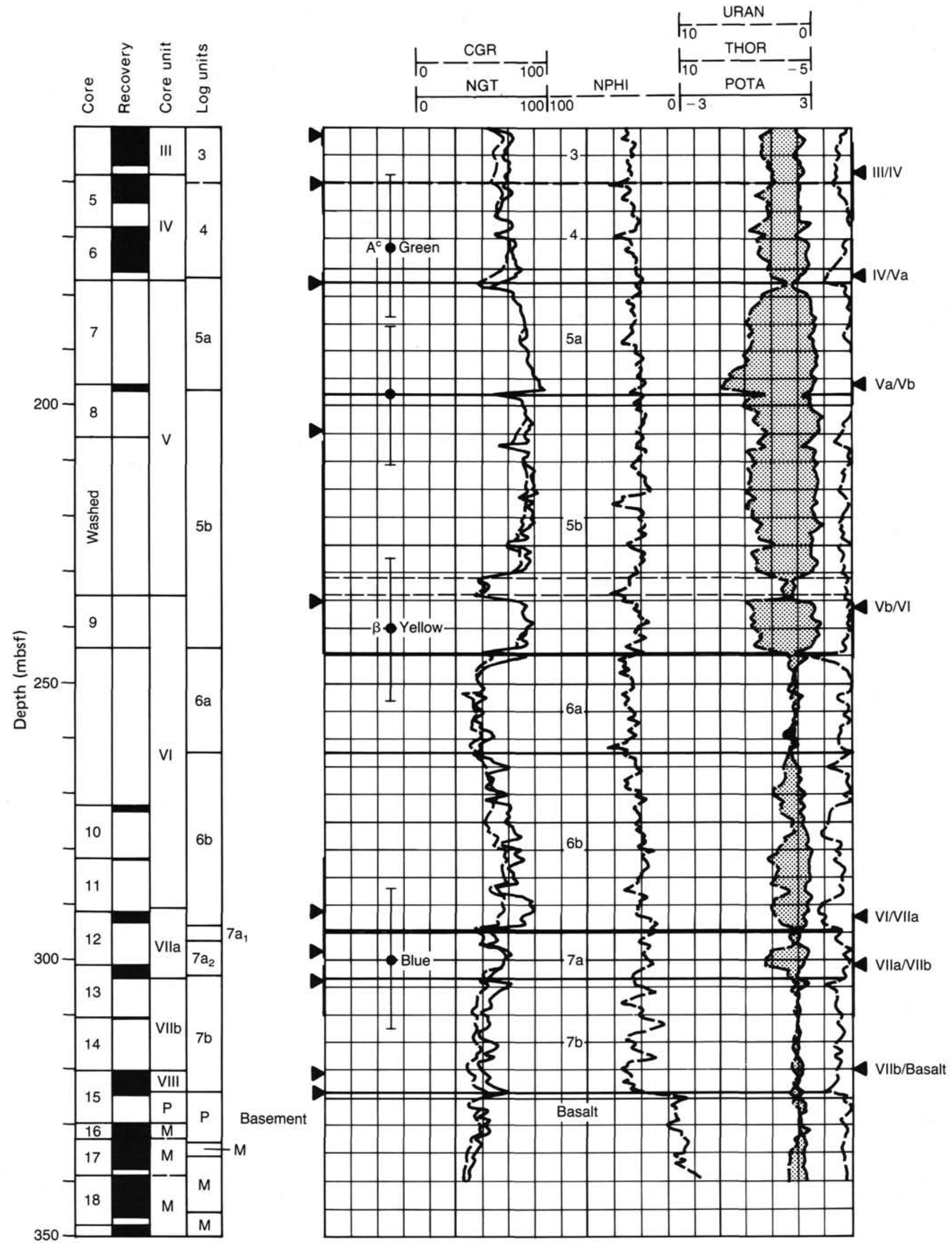

Figure 1 (continued). 
Table 2. Depths to unit boundaries.

\begin{tabular}{|c|c|c|c|c|}
\hline \multicolumn{2}{|c|}{ Log } & \multicolumn{3}{|c|}{ Core } \\
\hline $\begin{array}{l}\text { Log unit } \\
\text { boundary }\end{array}$ & $\begin{array}{l}\text { Depth } \\
\text { (mbsf) }\end{array}$ & $\begin{array}{l}\text { Lithologic } \\
\text { unit } \\
\text { boundary }\end{array}$ & $\begin{array}{c}\text { Depth } \\
\text { Hole 418A } \\
\text { (mbsf) }\end{array}$ & $\begin{array}{c}\text { Depth } \\
\text { Hole 418B } \\
\text { (mbsf) }\end{array}$ \\
\hline $1 / 2 a$ & 19 & I/IIa & - & 16 \\
\hline $2 a / 2 b$ & 77 & $\mathrm{IIa} / \mathrm{IIb}$ & - & $72-76$ \\
\hline $2 b / 3$ & 143 & IIb/III & $151-153$ & $136-148$ \\
\hline $3 / 4$ & 160 & III/IV & $159-164$ & $153-166$ \\
\hline $4 / 5 a$ & 178 & IV $/ \mathrm{Va}$ & $173-206$ & $171-177$ \\
\hline $5 a / 5 b$ & 198 & $\mathrm{Va} / \mathrm{Vb}$ & $197-206$ & $195-200$ \\
\hline $5 b / 6$ & 244 & $\mathrm{Vb} / \mathrm{VI}$ & $197-245$ & $235-244$ \\
\hline $6 / 7 a$ & 294 & VI/VIIa & $283-300$ & $285-300$ \\
\hline $7 a / 7 b$ & 302 & VIIa/VIIb & $303-310$ & $302-309$ \\
\hline $7 \mathrm{~b} /$ Basalt & 324 & VIII/Basalt & 324 & NA \\
\hline
\end{tabular}

in the analysis; the calculated depth to basement is $337 \mathrm{mbsf}$, just $13 \mathrm{~m}$ greater than the 324 mbsf depth found by drilling. This result indicates that the above equation should apply to Site 418 and can be used to estimate depths corresponding to seismic reflections independent of the coring results. Given the detail revealed by the NGT log, a refined correlation of reflectors with lithologic boundaries can thus be obtained.

We have re-evaluated the single-channel Glomar Challenger profile across Site 418, as shown in Figure 2; the reader is also referred to Figure 5 of Senske and Stephen (this volume). Our interpretation is summarized in Table 3. Calculated depths to reflecting horizons are also indicated in Figure 1.

Both primary reflections and second arrivals from the bubble pulse (designated $\mathrm{P}$ and $\mathrm{S}$, respectively) are recorded on the single-channel record (Fig. 2). Of the primary reflections, four correlate with those of Senske and Stephen (this volume): red $(0.09 \mathrm{~s})$, green $(0.21 \mathrm{~s})$, yellow $(0.29 \mathrm{~s})$, and blue $(0.36 \mathrm{~s})$. The events at $0,0.09,0.21$, and $0.29 \mathrm{~s}$ are followed by events at 0.03 , $0.12,0.24$, and $0.32 \mathrm{~s}$, respectively, suggesting that the pulse train consists of two arrivals separated by about $0.03 \mathrm{~s}$.

Two additional events can be tentatively identified. There is a strong pulse at $0.05 \mathrm{~s}$ not followed by a second arrival, which should be present if this is a primary reflection. We thus infer that the 0.05 -s event is a second arrival that follows a primary reflection at $0.02 \mathrm{~s}$ and is masked by the pulse train from the seafloor. The Leg 102 records (see Senske and Stephen, this volume, Fig. 5) also show a pulse at about $0.02 \mathrm{~s}$, but it may be a source artifact. The reflection at $0.24 \mathrm{~s}$ appears to be a second pulse. However, it is not parallel to the primary reflection at $0.21 \mathrm{~s}$, suggesting that it is a possible primary reflection partially masked by the bubble pulse from the preceding reflection. The Leg 102 profiles lend some credence to this interpretation. In Figure 5 of Senske and Stephen (this volume) the green reflector (at $0.20 \mathrm{~s}$ ) is a weak event followed by a stronger pulse at about $0.24 \mathrm{~s}$.

Using depths calculated from the model of Carlson et al. (1986) and referring to the coring and logging records, we correlate these reflectors with the lithostratigraphy as follows.

Event $1(0.02 \mathrm{~s})$ has an estimated depth of $16 \mathrm{mbsf}$, which correlates well with the contact between Units I and II in Hole 418B (16 mbsf) and with the log Unit 1/Unit 2 boundary in Hole 418A (19 mbsf). Thus, if this reflection is real, it represents the transition from the calcareous clay of Unit I to the noncalcareous clays of Unit II.

Event $2(0.09 \mathrm{~s})$ is the red reflector of Senske and Stephen (this volume). The calculated depth of $73 \mathrm{mbsf}$ correlates well with the contact between Subunits IIa and IIb in Hole 418B (73 mbsf) and with the contact between log Units $2 a$ and $2 b$ (77 mbsf). This reflection cannot be correlated with a specific feature such as an ash layer, although such a cause cannot be ruled out. A more likely cause of impedance contrast at this lithologic boundary is the higher smectite content of Subunit IIb (see Mann and Müller, 1980).

Event $3(0.21 \mathrm{~s})$ is the green reflector of Senske and Stephen, horizon $\mathrm{A}^{\mathrm{c}}$. If the statistical model of Carlson et al. (1986) is correct, this reflector does not correlate well with the Eocene zeolitic clay of Unit III. The calculated depth (173 mbsf) correlates most closely with the Unit 4/Unit 5 contact at 178 mbsf, where the smectite-rich Eocene clays of Unit IV are underlain by smectite-poor and illite-rich clays of Unit V (Mann and Müller, 1980); this change in mineralogical composition is a possible cause of the reflection.

Event $4(0.24 \mathrm{~s})$ is tentative because the second arrival from event 3 also occurs at this time. However, the calculated depth of 198 mbsf correlates exactly with the contact between log Units $5 \mathrm{a}$ and $5 \mathrm{~b}$ (lithologic Subunits $\mathrm{Va}$ and $\mathrm{Vb}$ ) where zeolitic clays of Late Cretaceous age are overlain by pelagic clays of uncertain age. Perhaps most significant is the correlation of this proposed reflection with the increase in shear strength and compressionalwave velocity that occurs between 190 and 200 mbsf (Donnelly, Francheteau, et al., 1980).

Event $5(0.29 \mathrm{~s})$ is the yellow reflector (Senske and Stephen, this volume). The estimated depth, $240 \mathrm{mbsf}$, correlates with the contact between log Units 5 and 6, the top of the Cretaceous "black clay" sequence. This correlation corroborates the conclusion of Senske and Stephen that this reflector is horizon $\beta$.

Event $6(0.36 \mathrm{~s})$ is the blue reflector of Senske and Stephen (this volume). The estimated depth of $300 \mathrm{mbsf}$ does not correlate with the sediment/basement contact at $324 \mathrm{mbsf}$. This depth does correlate with the contact between $\log$ Units $7 \mathrm{a}$ and $7 \mathrm{~b}$; thus it is likely that this reflection is caused by the contrast between the clays of Unit $7 \mathrm{a}$ and the underlying chalk of Unit $7 \mathrm{~b}$ rather than the top of basaltic basement.

\section{CONCLUSIONS}

The lithostratigraphy of the sediment section at DSDP Site 418 is poorly resolved by the coring record because of spot coring and poor recovery (Donnelly, Francheteau, et al., 1980) We have used the NGT log recorded on Leg 102 at Hole 418A to resolve the lithologic column in better detail. With the exception of the contact between $\log$ Units 3 and 4, log-unit boundaries are sharply defined and can be resolved to within about $1 \mathrm{~m}$. In general, log units correspond closely with the lithologic units defined by coring; with one exception, depths to log-unit and lithologic-unit boundaries correspond to within about $4 \mathrm{~m}$. The exception is the top of lithologic Unit VI (the "black clay facies") that is clearly defined by the log at a depth of 244 mbsf, as opposed to the $235 \mathrm{mbsf}$ depth proposed on the basis of the cores. Furthermore, depths to all log-unit boundaries correspond to lithologic-unit boundaries within the uncertainties of the coring record (see Table 2). This close correspondence testifies to the care and insight of the shipboard scientists in analyzing the cores (Donnelly, Francheteau, et al., 1980).

Based on the detailed lithostratigraphy revealed by the log and by using a statistical model relating depth to traveltime in deep-sea sediments (Carlson et al., 1986), we have also made a detailed correlation of seismic reflectors with lithologic boundaries at Site 418 . Of the five reflectors considered, three correspond to events also described by Senske and Stephen (this volume), and all can be correlated with lithologic boundaries. In particular, a reflection at $0.21 \mathrm{~s}$, which has been identified as horizon $\mathrm{A}^{\mathrm{c}}$ by Senske and Stephen, correlates with the base of the Eocene clays of Unit 4, at a depth of 172 mbsf. Similarly a reflector at $0.29 \mathrm{~s} \mathrm{(} 240 \mathrm{mbsf})$ correlates with the top of the "black clay facies," Unit VI. This correlation confirms the conclusion of Senske and Stephen (this volume) that this reflector is 


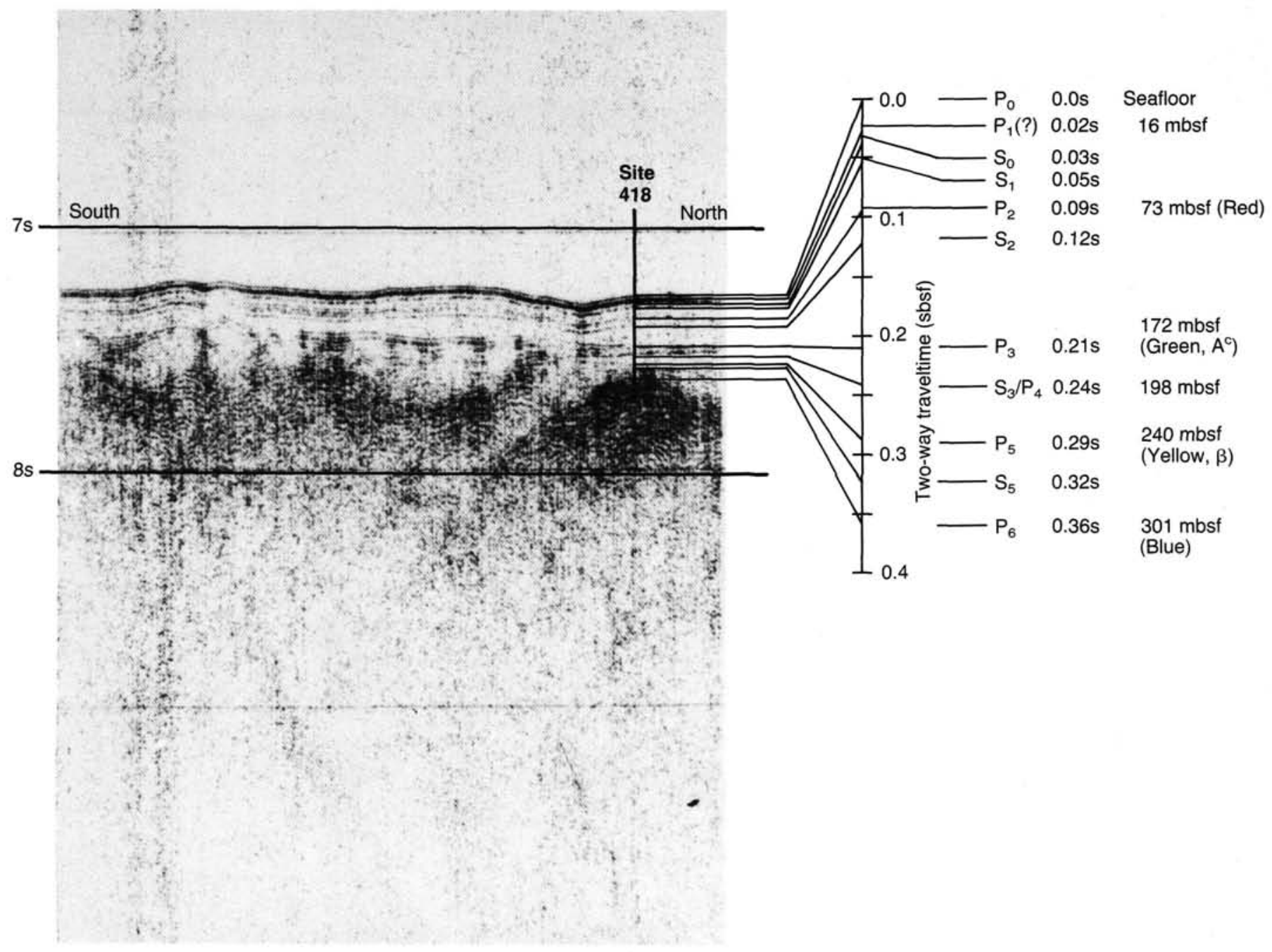

Figure 2. Interpreted reflection profile across Site 418. $\mathrm{P}$ indicates primary event. $\mathrm{S}$ indicates second pulse. Subscripts denote reflectors (i.e., $\mathrm{P}_{2}$ and $\mathrm{S}_{2}$ represent the same reflecting horizon). The existence of $P_{1}$ is inferred from $S_{1} \cdot P_{4}$ is partly masked by $S_{3}$.

Table 3. Reflection traveltimes and calculated depths.

\begin{tabular}{|c|c|c|c|}
\hline Event & $\begin{array}{l}\text { Two-way } \\
\text { traveltime } \\
\text { (sbsf) }\end{array}$ & $\begin{array}{l}\text { Calculated } \\
\text { depth } \\
\text { (mbsf) }\end{array}$ & Remarks \\
\hline $\mathrm{P}_{0}$ & 0.00 & 0 & Seafloor \\
\hline $\mathrm{S}_{0}$ & 0.03 & - & Second pulse from seafloor \\
\hline$P_{1}$ & 0.02 & 16 & $\begin{array}{l}\text { Inferred primary pulse preced- } \\
\text { ing pulse at } 0.05 \mathrm{~s}\end{array}$ \\
\hline $\mathrm{S}_{1}$ & 0.05 & - & Probable second pulse \\
\hline$P_{2}$ (red) & 0.09 & 73 & Primary reflection \\
\hline $\mathrm{S}_{2}$ & 0.12 & - & Probable second pulse \\
\hline $\mathrm{P}_{3}$ (green, $\mathrm{A}^{\mathrm{C}}$ ) & 0.21 & 172 & Primary reflection \\
\hline $\mathrm{S}_{3} / \mathrm{P}_{4}$ & 0.24 & 198 & $\begin{array}{l}\text { Probable primary reflection, } \\
\text { not parallel } 0.21-\mathrm{s} \text { reflector, } \\
\text { partially masked by } \mathrm{S}_{3}\end{array}$ \\
\hline $\mathrm{P}_{5}$ (yellow, $\beta$ ) & 0.29 & 240 & Reflector poorly defined \\
\hline $\mathrm{S}_{5}$ & 0.32 & - & Probable second pulse \\
\hline $\mathrm{P}_{6}$ (blue) & 0.36 & 301 & Primary reflection \\
\hline
\end{tabular}

horizon $\beta$, which is widespread in the western North Atlantic and represents a Cretaceous transition from carbonate to noncalcareous deposition. The reflection at $0.36 \mathrm{~s}$ (blue) probably correlates with the top of chalk (Unit 7b) overlying basement.

\section{ACKNOWLEDGMENTS}

We wish to thank Captain Oonk and the crew of the JOIDES Resolution and the ODP shipboard and shore-based staff for the success of logging operations on Leg 102.

Texas A\&M Geodynamics Research Institute contribution no. 65.

\section{REFERENCES}

Carlson, R., Gangi, A., and Snow, K., 1986. Empirical reflection travel time versus depth and velocity versus depth functions for the deepsea sediment column. J. Geophys. Res., 91:8249-8266.

Donnelly, T., Francheteau, J., Bryan, W., Robinson, P., Flower, M., Salisbury, M., et al., 1980. Init. Repts. DSDP, 51, 52, 53: Washington (U.S. Govt. Printing Office).

Ewing, M., and Ewing, J. I., 1963. Sediments at proposed LDGO drilling sites. J. Geophys. Res., 68:251-256.

Mann, U., and Müller, G., 1980. X-ray mineralogy of Deep Sea Drilling Project Legs 51 through 53, western North Atlantic. In Donnelly, T., Francheteau, J., Bryan, W., Robinson, P., Flower, M., Salisbury, M., et al., Init. Repts. DSDP, 51, 52, 53, Pt. 2: Washington (U.S. Govt. Printing Office), 721-730.

Salisbury, M., Scott, J., et al., 1986. Proc. ODP, Init. Repts., 102: College Station, TX.

Tucholke, B. E., 1979. Relationships between acoustic stratigraphy and lithostratigraphy in the western North Atlantic Basin. In Tucholke, 
R. L. CARLSON, R. H. WILKENS, D. MOOS, C. BROGLIA

B. E., Vogt, P. R., et al. Init. Repts. DSDP, 43: Washington (U.S. Govt. Printing Office), 827-846.

Tucholke, B. E., and Mountain, G. S., 1979. Seismic stratigraphy, lithostratigraphy and paleosedimentation patterns in the North American Basin. In Talwani, M., Hay, W., and Ryan, W.B.F. (Eds.), Deep Drilling Results in the Atlantic Ocean: Continental Margins and Pa- leoenvironments. Am. Geophys. Union, Maurice Ewing Ser., 3:5886.

Date of initial receipt: 17 February 1987

Date of acceptance: 5 August 1987

Ms 102B-110 